\title{
The Character Development of Students at SMKN 3 Salatiga Through Extracurricular Activities In 2018/2019 Academic Year
}

\author{
Intan Putri Setyani ${ }^{*}$, Nani Mediatati ${ }^{2}$
}

1,2 Program Studi PPKn, FKIP Universitas Kristen Satya Wacana

A R T I C L E I N F O

Article history:

Received 15 February

2019

Received in revised

form

29 March 2019

Accepted 18 April 2019

Available online 25 May

2019

Keywords:

Extracurricular, Scout, Character

\section{A B S T R A C T}

This study aimed to describe the character development of Students at SMKN 3 Salatiga through scout extracurricular activities in] 2018/2019 academic year. The subject of this research were tenth grade students of SMKN 3 Salatiga, amount to 227 students. This research is Qualitative research. The data collected by interviews, observation and questionnaires. The results showed that the characters of students formed and fostered in scout extracurricular activities were religious characters, love of nature, caring for others, patriotism, deliberation, cooperation, skillful, discipline, responsible, honest, love the motherland. Scout activities programs that are designed and implemented to shape and foster student character include training, bantara monitoring, Outbound, Deliberation, camp, flower sowing, and ETK. The success of students' character formation and coaching through the scout program reached an average of $90.08 \%$ with a very good category. 


\section{Introduction}

Undang-Undang No.23 Tahun 2003 tentang Sistem Pendidikan Nasional Pasal 1 Ayat 1 states that "Education is a conscious effort to create an atmosphere of learning and learning process so that students actively develop their potential to have religious spiritual strength, self-control, personality , intelligence, noble character, and the skills needed by himself, the people of the nation, and the country ". Education in schools aimed at developing intelligence, skills and attitudes / characters of students is carried out both through extracurricular and extracurricular activities. Extracurricular activities carried out during school hours with the aim of maximizing teaching and learning activities of each subject. While extracurricular activities are activities outside of school hours that have the aim of developing students, for example , Intra-School Student Organizations (OSIS), Scouts, Paskibra, and others. According to Mursitho (2010: 26), extracurricular activities are "one of the operational set of activities ( supplements and complements) in the school curriculum carried out outside the classroom, aiming that students can further enhance their abilities about what has been and will be learned in intracuricular activities, as well as channeling Interest talents and help realize character formation in learners ".

SMKN 3 Salatiga with a vocational school background has several extracurricular activities aimed at shaping and fostering the character of students, one of which is scouting, and must be followed by all students. Based on Permendikbud No. 63 Tahun 2014 Pasal 2 states that scouting education is carried out as a compulsory extracurricular activity in primary and secondary education, extracurricular activities are mandatory extracurricular activities that must be attended by all students.

In general explanation of Undang-Undang No. 12 Tahun 2010 that concern about Scout, it emphasized that the scouting movement functions as a forum to achieve the goals of scout through scouting activities namely education and training, development, community service and parents, as well as educational-oriented games. The purpose of the scouting movement is to form each scout to have a faithful, pious, noble character, patriotic spirit, obey the law, discipline, uphold the nation's noble values, and have the life skills as a cadre of the nation in protect and develop Negara Kesatuan Republik Indonesia, Pancasila practice, and preserve the environment. Referring to UU No. 12 Tahun 2010 and Permendikbud No. 23 Tahun 2014, the scout extracurricular activities carried out in elementary schools through to high schools and must be followed by all students in the context of carrying out character education so that students are formed with good character.

Based on documentary studies and interviews with one of the counseling teachers at SMKN 3 Salatiga, it was found that there are still many tenth grade students whose characters are not good, such as truant, late, lack of motivation to follow the lessons, do not follow school rules, and Other information can be seen in the following Table.

Table 1. Number of tenth grade students of SMKN 3 Salatiga who are less attitude / character 2017-2018 academic year.

\begin{tabular}{lllll}
\hline \multirow{2}{*}{ No. } & \multirow{2}{*}{ Character } & Gender & & \multirow{2}{*}{ Total } \\
\cline { 3 - 4 } & & Man & Girl & \\
\hline 1 & Frequent truant & 20 & 5 & 25 \\
2 & Late & 30 & 20 & 50 \\
3 & Not doing Tasks & 25 & 15 & 40 \\
4 & Noisy / noisy during class time & 25 & 10 & 35 \\
5 & Playing cellphone during class & 15 & 10 & 25 \\
6 & Not following religious activities & 30 & 15 & 45 \\
7 & Not in full uniform & 40 & 10 & 50 \\
8 & Not following Monday's ceremony & 25 & 12 & 37 \\
9 & Not following the national holiday ceremony & 20 & 10 & 30 \\
10 & Fighting with friends & 15 & 0 & 15 \\
Total & & $\mathbf{2 4 5}$ & $\mathbf{1 0 7}$ & $\mathbf{3 5 2}$ \\
\hline
\end{tabular}

The characters are less well it could be due to several factors, such as: lack of attention from parents, not good social environment, the negative influence of social media, and so forth. Lack of attention from parents causes students to not have the enthusiasm and motivation to study at school, so 
students don't leave / skip places elsewhere. A bad social environment causes students to have disobedient attitudes and feel free to be free without rules, for example not wanting to obey the rules at school, not following the required activities, going home before school hours and others. The current use of social media can influence student behavior and can have a negative impact if students are not good at sorting and filtering out good things, for example in order to follow their idols in social media, students use excessive esophageal, the use of piercing in men, dye your hair with a striking color to follow fashion, be consumed by hoax or hoax news related to education, country, and issues in society.

SMKN 3 seeks to develop good character from students through various extracurricular activities, and the mandatory for tenth students is scout. Through various programs implemented in extracurricular activities that scouts should promote religious character, love of nature, care about others, patriotism, consultation, cooperation, skilled, thrift, discipline, responsibility, honesty, love of the homeland of the students.

Based on these problems, a study was conducted on Scout extracurricular activities program that was designed and implemented to shape and foster the character of SMKN 3 Salatiga students in the 2018/2019 school year and the effectiveness of its success. From the results of previous research by Afroh Nailil Hikmah (2015) entitled "Upaya Pembentukan Karakter Siswa melalui Kegiatan Ekstrakurikuler Pramuka di SDIT Salsabila 2 Klaseman Sindhuharjo Ngaglik Sleman ", showed that through extracurricular activities the students can train to have a strong spirit of unity, have an active activities in high discipline, independence, honesty, cooperation, responsibility, and democracy with an $85 \%$ success rate..

\section{Methods}

This type of research is a qualitative descriptive study, with the aim of describing the formation and fostering of the character of SMKN 3 Salatiga students through scout extracurricular activities. In this study, techniques and data collection instruments were used in the form of interview guidelines, observation guidelines, and questionnaires to collect data about the planning, implementation, and success of Scouting activity programs in developing the character of SMKN 3 Salatiga students. Data collected through data collection techniques is raw data that will be processed using data analysis techniques / models according to Miles and Huberman (2014: 10), which consists of three activities that occur simultaneously, namely: data reduction, data presentation, drawing conclusions /verification. To obtain the validity of the data researchers used source triangulation techniques and data collection techniques.

\section{Result And Discussion}

The character of students formed and fostered through scout extracurricular activities at SMKN 3 Salatiga is religious character, love for nature, caring for others, patriotism, deliberation, cooperation, skillful, economical, disciplined, responsible, honest, loving the motherland. Religious characters are formed and fostered in the program of activities designed and implemented, namely monitoring of the bantara. Candidates for Bantara are required to complete the SKU enforcement, SKU (Syarat Kecakapan Umum), which includes religious activities, prayers, and legal teachings of each faith, for example if a Muslim participant is obliged to explain the pillars of Islam. This is in accordance with Anggaran Dasar Gerakan Pramuka bab 3 pasal 7 which states that the scout is religious, it means that the scout obliged to foster and increase the faith and piety of its members, the scouting movement is able to develop harmony of life between religious communities, members of the scout are obliged to embrace religion and worship according to their respective religions and beliefs. (Munaslub 2012:3). Therefore this activity aims to shape the religious character of students so that they are more devoted to God Almighty.

Furthermore, the nature love character is formed and fostered through outbound activities. Outbound is a learning activity from a variety of applied sciences conducted in the open environment in the form of effective games, such as exploring, the challenge of finding medicinal plants, flying fox, two line brige, spider web. The form of the game involving objects that exist in nature is an effort to recognize the benefits of nature for human survival. This is in accordance with the basic principles of the Household Scout Movement article 9 paragraph 3c namely the practice of values and the basic principles of scouting are implemented in the form of preserving a clean and healthy environment in order to support and provide comfort and prosperity for the community (Munaslub 2012: 4). Therefore the formation and formation of the character of love of nature is done through outbound so that students have an awareness of the importance of nature for human survival.

The character of caring for others is formed and fostered through routine training activities, in routine training there are various activities that can instill the values of caring, one of which is social 
service activities. Social service is a form of caring for fellow human beings, especially people in need. The form of this activity is in the form of cleaning in the community, providing food assistance to families in need. Through this activity students are invited to engage in the community environment, so they can feel directly the pattern of community life, and have a sense of caring about social problems that exist in society. In routine training there are also various activities including pioneering / rigging, LBB (marching exercise), PPGD (Emergency First Aid) skills, morshe and semaphore skills and so on. In pioneering / rigging skills, students are taught various skills such as the construction of tents with special techniques, the making of crafts with materials in nature. Pioneering (rigging) is a technique of using hemp rope which is assembled into an object, such as a creative building, a stretcher, a flagpole buffer, turret tower, tent, shoe rack, and other objects. After students learn and practice the techniques taught, students are expected to have skilled characters in the use of simple materials that are made into useful works, so that they can be applied in daily life. Furthermore LBB (marching exercise) is a skill to carry out commands according to instructions related to physical movements. These marching skills are used to train students' discipline, harmony, cohesiveness, and the art of marching, so that students have a disciplined and compact character. PPGD (Pertolongan Pertama Gawat Darurat) is an activity to provide first aid to accident victims or sick people. What is done in this activity is to provide temporary relief measures by providing medicines and preventive measures so that serious injuries do not occur, and the next step is handed over to the nearest health center or hospital. With this activity, for example, dressing the wound using a splint and mitela is expected to form the character of accuracy, patience, cooperation, responsibility, and social care. Furthermore, the skills of morshe and semaphore, which are the scouting languages. The difference between the two lies in the use of media. Morse uses the media of whistles, flashlights, flags, and massages. Semaphore uses a small flag media measure in $45 \mathrm{~cm} \mathrm{x} 45 \mathrm{~cm}$. This skill needs to be possessed by each scout member so that in an emergency they can still deliver a message. Through this activity, it is expected to be able to shape the character of accuracy, accuracy, responsibility and patience. In routine training also formed the character of discipline, responsibility, and honesty, because in every routine training activity sanctions were imposed on students who violated the rules of scouting, such as penalties for delay, completeness of attributes, and others. It aims to provide a warning and deterrent effect so that violations are not repeated. The habit of forming disciplined characters in each exercise is very influential for students when working and mingling with the community.

The character of responsibility is formed and fostered in routine training activities with the enactment of the use of the complete attributes of the Boy Scout uniform. Every student is obliged to use complete attributes, ranging from hats, bet, hasduk, black socks, and black shoes, etc., if students do not use complete attributes or violate uniformed provisions, they will be subject to punishment. This aims to form a sense of responsibility, if students are able to take responsibility for what they wear, and then students are expected to be able to be responsible to others and the environment.

Then honest character is fostered through the application of individual absence systems and at every routine training meeting. The use of individual absences is expected to be able to train the honesty of students, because the filling in absences is done by the students themselves, although they are still supervised by the coach. If students on the day and date of the training activity do not leave but there is a name printed, then the coach will impose sanctions, as well as students who fill the absences of their friends who do not leave on the training day. Every time a meeting is held in a training activity, the coach has his own absence to be matched with the absence filled out by students. This is done to test the honesty of students and to practice honest character in students. In the routine training activities carried out by SMKN 3 Salatiga it has reflected the objectives of the pattern and mechanism for scouting the national scout enforcement scouts of the scout movement No. 176 of 2013, namely scouting enforcement scouts is the process of education and fostering personality, character, character, knowledge, skills, dexterity, health, and physical fitness, and leadership for scouting enforcers so that they can live independently. Therefore, in routine activities play a large role in the formation and formation of student characters, because in their implementation there are many activities related to the formation and formation of students' characters.

The character of patriotism in scouting activities is formed through the sowing of flowers. The sowing of the flowers is held every memorial day of the heroes at the hero's grave to commemorate the services of the heroes, the activity is in accordance with the objectives of the Keputusan Musyawarah Nasional (MUNAS) Gerakan Pramuka No. 11 Tahun 2013 pasal 3a which contains the scout movement aims to form every scout has a personality that is faithful, pious, noble, patriotic, law-abiding, disciplined, upholds the nation's noble values, life skills, healthy physical and spiritual. therefore these activities can foster the character of patriotism of each student by living up to the sacrifice of the heroes who have fallen defending the nation. 
Furthermore, the character of the deliberations in the implementation of scout activities was formed in the MA activities (Deliberation Conference) held by the ambalan board at the end of each semester to conduct evaluation and program planning in the following semester. Each representative is included to provide an opinion to evaluate the activities that have been carried out, and to improve the program of further activities. This is reflected in the adoption of the Boy Scout Movement's code of ethics scout chapter IV article 14g which contains the code of honor scout practiced in the form of listening to, appreciating, and accepting the opinions or ideas of others, controlling oneself, being open, obeying agreements and taking into account the common interests, give priority to unity and unity as well as speak words and behave in courtesy, friendly and patient (Munaslub 2012: 8). From these activities students are expected to have a deliberative character, so students dare to voice their opinions well and politely and be able to respect the opinions of others.

The character of cooperation is formed and fostered in the activities of ETK (Estafet Kelapa Relay) whose implementation requires teamwork / groups to unite in the ETK procession (Estafet Kelapa Relay), where each member carries equipment and has their respective duties to go through a long route. This activity is in the form of a walk of an army of scouts carrying various attributes such as the red and white flag, scout flag, torch, coconut shoots and several other attributes. The coconut shoot relay is relayed with a distance of $5 \mathrm{~km}$ each stage, and there are various group arrangements with their respective assignments. The activity is in accordance with the scouting education system of the household scout chapter IV chapter 16 movement scouts namely group scout activities providing opportunities for learning to lead and be led, organize and be organized, organize, take responsibility, and cooperate in harmony (Munaslub 2012: 9). With the existence of the ETK (Estafet Tunas Kelapa) activity, it is expected that each student will have an initiative of responsibility and be able to work well together with their respective assignments.

Thrifty characters are formed and fostered in camp activities. One of the camping activities that train students to be independent and economical is cooking activities, the implementation of which requires students to use simple materials that are available in nature, starting from making stoves using stone stacks and twigs as fuel so that they can save fuel oil. Students are required to bring food ingredients such as sweet potatoes, corn, beans to be processed during the activity. The activity is in accordance with the seventh practice of darma that is careful saving and understated, which means acting and living frugally, not excessive, conscientious, cautious and not doing things that are redundant by getting used to a modest life in preparation to be able to overcome various challenges in life (Dimas Rahmat 2010: 29). From these activities, it can train students to save money by utilizing natural materials in everyday life.

The love character of the motherland is also formed and fostered in every scouting activity. Religious character, love of nature, caring for others, patriotism, deliberation, cooperation, skilled, economical, disciplined, responsible and honest are components of the character of patriotism. This is in accordance with the Articles of Association of the Scout Movement article 8 paragraph 2 which contains scouting education is a practical educational process, outside the school and family education system carried out in the open in the form of activities that are interesting, challenging, enjoyable, healthy, organized, and directed, by applying the basic principles of scouting and scouting methods to form personalities and characters that are noble, independent, caring, love the motherland, and have life skills (Munaslub 2012: 3). Therefore, through scouting activities it is expected that students as the next generation of the nation will be able to become individuals who have noble character, love Indonesian nature, care for fellow countrymen, have the character of deliberation as one form of Indonesian democracy, able to work together to advance the nation's life, be skilled, economical, disciplined, responsible and honest.

The level of success of various scout activities programs in shaping and fostering religious character, loving nature, caring for others, patriotism, deliberation, cooperation, skilled, economical, disciplined, responsible, honest, patriotism can be shown from the results of questionnaire data filled out by students as following:

Table 2. Table of the success rate of forming and fostering student character through scout activities

\begin{tabular}{lllll}
\hline No. & Character & total & Percentage & Category \\
\hline 1 & Religious & 202 & $91.50 \%$ & Very good \\
2 & Love nature & 201 & $91.00 \%$ & Very good \\
3 & Care to each other & 200 & $90.50 \%$ & Very good \\
4 & Patriotism & 196 & $89.00 \%$ & Very good \\
5 & discussion & 195 & $88.50 \%$ & Very good \\
6 & Cooperation & 198 & $90.00 \%$ & Very good \\
\hline
\end{tabular}




\begin{tabular}{lllll}
\hline 7 & Skilled & 202 & $91.50 \%$ & Very good \\
8 & Thrifty & 195 & $88.50 \%$ & Very good \\
9 & Discipline & 200 & $90.50 \%$ & Very good \\
10 & Responsible & 201 & $91.00 \%$ & Very good \\
11 & Honest & 198 & $90.00 \%$ & Very good \\
12 & Love the motherland & 196 & $89.00 \%$ & Very good \\
Average & & 2384 & $90.08 \%$ & Very good \\
\hline
\end{tabular}

Table 3. Information:

\begin{tabular}{ll}
\hline INTERVAL & CATEGORY \\
\hline $81 \%-100 \%$ & Very good \\
$61 \%-80 \%$ & Well \\
$41 \%-60 \%$ & Enough \\
$21 \%-40 \%$ & Less \\
$0 \%-20 \%$ & Very less \\
\hline
\end{tabular}

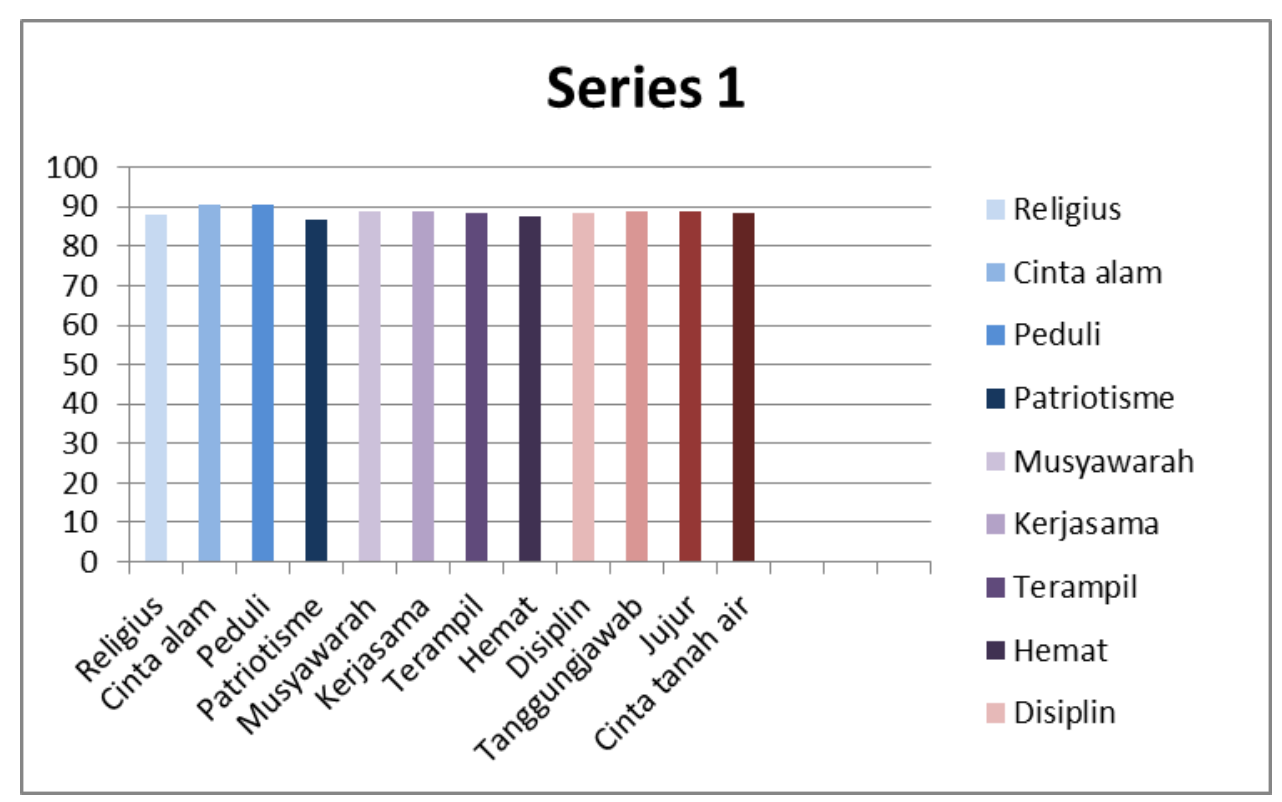

Figure 1. Graph of the success rate of forming and fostering student character through scout extracurricular activities

Based on the table and graph above, It showed the level of success of the scout program activities in developing students character with the following description: religious characters $91.50 \%$, nature love characters $91.00 \%$, caring characters $90.50 \%$, patriotism characters $89.00 \%$, character of deliberation 88.50\%, 90.00\% cooperation character, $91.50 \%$ skilled character, $88.50 \%$ saving character, $90.50 \%$ discipline character, $91.00 \%$ responsibility character, $90.00 \%$ honest character, homeland love character get $89.00 \%$ percentage, the average level of success of scouting activities in forming and fostering student character by $90.08 \%$, with a very good category.

The results of this questionnaire were also supported by the results of interviews with scout coaches who stated that: "Scout extracurricular activities can develop students' character better, students who initially had less interest in scout activities are becoming diligent in following activities routinely, and students who initially often skip classes do not have the motivation to study were more diligently leaving and wanting to take lessons, students who go home before school hours, now go home on time and take lessons until the end of the class" 


\section{Conclussion}

From the results of the study and discussion the following conclusions are:

1. The character of students formed and fostered through scout extracurricular activities is religious character, love of nature, caring for others, patriotism, deliberation, cooperation, skilled, economical, disciplined, responsible, honest, loving the motherland.

2. Scout extracurricular activities that are designed and implemented to shape and foster student character include routine training, bantara monitoring, Outbound, MA (Ambalan Deliberation), camp, flower sowing, ETK (Estafet Tunas Kelapa).

3. The successful formation and formation of characters through various activities in scout extracurricular activities reached $90.08 \%$ in the excellent category.

Based on the conclusions, the authors provide the following suggestions:

1. For schools

So that the implementation of scouting activities can shape the character of students better, schools are expected to be able to complete the supporting facilities for scouting extracurricular activities, so that there are no obstacles or obstacles in the implementation of activities.

2. For the coach

It is expected that the coaches can develop more innovative skills and conduct new activities that can shape the character of students in a fun way, so that students are more enthusiastic in participating in scouting activities.

3. For students

Students are expected to be more active in participating in scout extracurricular activities because there is a lot of knowledge and character values that can be applied in daily life

\section{Reference}

Anggaran Dasar Gerakan Pramuka Hasil Munaslub Gerakan Pramuka Tahun 2012. Jakarta

Anggaran Rumah Tangga Gerakan Pramuka Hasil Munaslub Gerakan Pramuka Tahun 2012. Jakarta

Azwar, Azrul. 2013. Gerakan Pramuka: Petunjuk Penyelenggaraan Pola dan Mekanisme Pembinaan Pramuka Penegak dan Pramuka Pendega. Jakarta: Kwartir Nasional Gerakan Pramuka.

Joko, Mursitho. 2010. Upaya Menumbuhkan Karakter Bangsa melalui Kegiatan Kepramukaan di Sekolah. Jakarta: Bumi Aksara.

Kwarnas. 2014. Musyawarah Nasional Gerakan Pramuka No. 11 Tahun 2013. Semarang: Kwarda Gerakan Pramuka Jawa Tengah.

Kwarnas. 2011. Syarat-Syarat Kecakapan Umum (SKU) Golongan Penegak dan Pandega. Jakarta: Kedai Kwartir Nasional Pramuka.

Miles, Mattew B, Amichael Huberman dan Saldana, J. 2014. Qualitative Data Analysis, A Methods Sourcebook, Edition 3. USA: Sage Publications. Terjemahan Tjetjep Rohindi Rohidi. Jakarta: Universitas Indonesia - Press.

Muslich, Masnur. 2011. Pendidikan Karakter: Menjawab Tantangan Krisis Multidimensional. Jakarta: PT Bumi Aksara.

Rahmat, Dimas. 2010. Buku Materi Pramuka Penegak: Ambalan Pandawa Srikandi Gudep 04. 137-04. 134. Grobogan: SMA Negeri 1 Purwodadi. 